\title{
BRNĚNSKÝ KNIHKUPEC A TISKAŘ FRANZ GASTL*
}

\author{
Lucie Heilandová (Praha)
}

\section{The Brno Bookseller, Publisher and Printer Franz Gastl}

\begin{abstract}
The company of Johann Georg Gastl and his sons was one of major printing and bookselling houses operating in Brno in the middle of the 19th century. Johann Nepomuk Gastl and his younger brother Franz Gastl had trained as booksellers. Johann Nepomuk Gastl assumed the management of the company after the death of Johann Georg Gastl. The younger Franz joined the family business in 1821 and between 1821-1829 worked as a bookseller in Olomouc. He moved to Brno in 1829 and took over the management of the publishing house and bookstore. He founded the first public book-rental shop at the bookstore in 1831. His brother decided to sell him his printing business in 1836, which made Franz Gastl the sole owner of an ever-growing company (the company of Franz Gastl became a printing company, lithographic shop, type foundry, publishing house, bookstore and book-rental shop). Franz Gastl died in 1855, and his company was taken over by his son Georg Gastl, who continued his father's activities.
\end{abstract}

Keywords: bookstore - printing company - lithographic shop - publishing house - Brno

V průběhu 19. století došlo v reakci na rozrůstající se čtenářskou obec a s tím související stoupající poptávku k rozšíření nabídky produkce tiskáren, v jejichž edičním plánu se vedle odborných nebo náboženských děl začínají hojně objevovat učebnice a učební materiály, populární literatura nebo tiskopisy a nejrůznější administrativní a akcidenční tisky. Většina moravských, především pak brněnských zakázek byla v této době rozdělena mezi stále se rozvíjející trasslerovsko-rohrerovskou tiskárnu a tiskárnu Johanna Georga Gastla a jeho dědiců. Obě rodinné tiskařské firmy byly navázány na rozsáhlou knihkupeckou sít' s kontakty nejen na Moravě nebo ve Slezsku, ale také např. v Krakově, Lipsku nebo ve Vídni. Vedle vlastní tiskárny a kamenotiskárny bylo nedílnou součástí obou výše zmíněných tiskařských firem nejen vlastní dobře zásobené knihkupectví s minimálně jednou filiálkou, ale také půjčovna knih či čtenářský kabinet.

Zakladatelem rodinné firmy sestávající z knihkupectví, obchodu s hudebninami a uměleckými předměty, knihtiskárny a později i kamenotiskárny byl Johann Georg Gastl (1766-1814) působící od roku 1782 v brněnské filiálce vídeňského knihkupectví Johanna Georga Weinganda, kde měl bezprostřrední možnost se seznámit $\mathrm{s}$ čtenářským publikem, poznat jeho vkus a zájmy. V roce 1785 se Johann Georg Gastl osamostatnil, začal ve větší míře spolupracovat s brněnskými tiskaři a stále více se zapojovat do vydávání knih, především pak učebnic. V roce 1805 se proto rozhodl využít př́ležitosti a koupit od Františka Karla Siedlera jeho tehdy upadající tiskárnu. Za celý Siedlerův podnik s vybavením i s domem zaplatil 60000 zlatých a položil tak základ jedné z nejvýznamnějších tiskařských a vydavatelských firem působících v Brně v první polovině 19. století. ${ }^{1}$ Johann Georg Gastl si během několika let vybudoval na brněnském knižním trhu význačné postavení, díky kterému měl přímý vliv na čtenářství brněnských a později i olomouckých měšt’anů. V tiskárně Johanna Georga Gastla byly vydávány odborné i populární publikace různých žánrů, zábavné čtení, německy a česky tištěné učebnice, katechismy, divadelní hry, hudebniny, periodika, brněnské adresáře, kuchařky nebo právnické tisky. Gastl rovněž inicioval publikování právních i hospodářských př́ruček určených pro laickou i odbornou veřejnost. Po koupi tiskárny také začal ve větší míře spolupracovat s moravskými správními úrady, kde si díky uzavřeným smlouvám zajistil privilegium na tisk učebnic pro normální školu, privilegium na vydávání schematismů, úředních tiskopisů, zákoníků, vyhlášek a dalších drobných tisků tištěných pro potřeby na Moravě sídlících úřadů. Řadu privilegií si podrželi i jeho synové, kteří rovněž plynule navázali na jeho vydavatelskou i knihkupeckou činnost.

Po smrti Johanna Georga Gastla dne 5. ledna 1814 se vedení firmy ujal tehdy skoro 30letý Johann Nepomuk Gastl (1785-1861) a až do plnoletosti svého bratra Franze de Pauly Gastla (1798-1855)² úspěšně řídil jak celý brněnský podnik,

\footnotetext{
* Tento př́spěvek vznikl na základě institucionální podpory dlouhodobého koncepčního rozvoje Národní knihovny Č́R jako výzkumné organizace poskytované Ministerstvem kultury ČR (DKRVO 2019-2023).

1 „Das radicirte Buchdruckerei-Recht nebst der Buchhandlung und dem Siedler'schen Hause Nro. 446 in der Postgasse und dem auf 17.000 fl. geschätzten Verlage löste Gastl 1805 um 60.000 fl. von Carl Siedler an sich. “ELVERT 1854, s. 99. Více o tiskárně J. G. Gastla viz HEILANDOVÁ 2017, s. 47-56.

2 Dále jen Franz Gastl.
} 


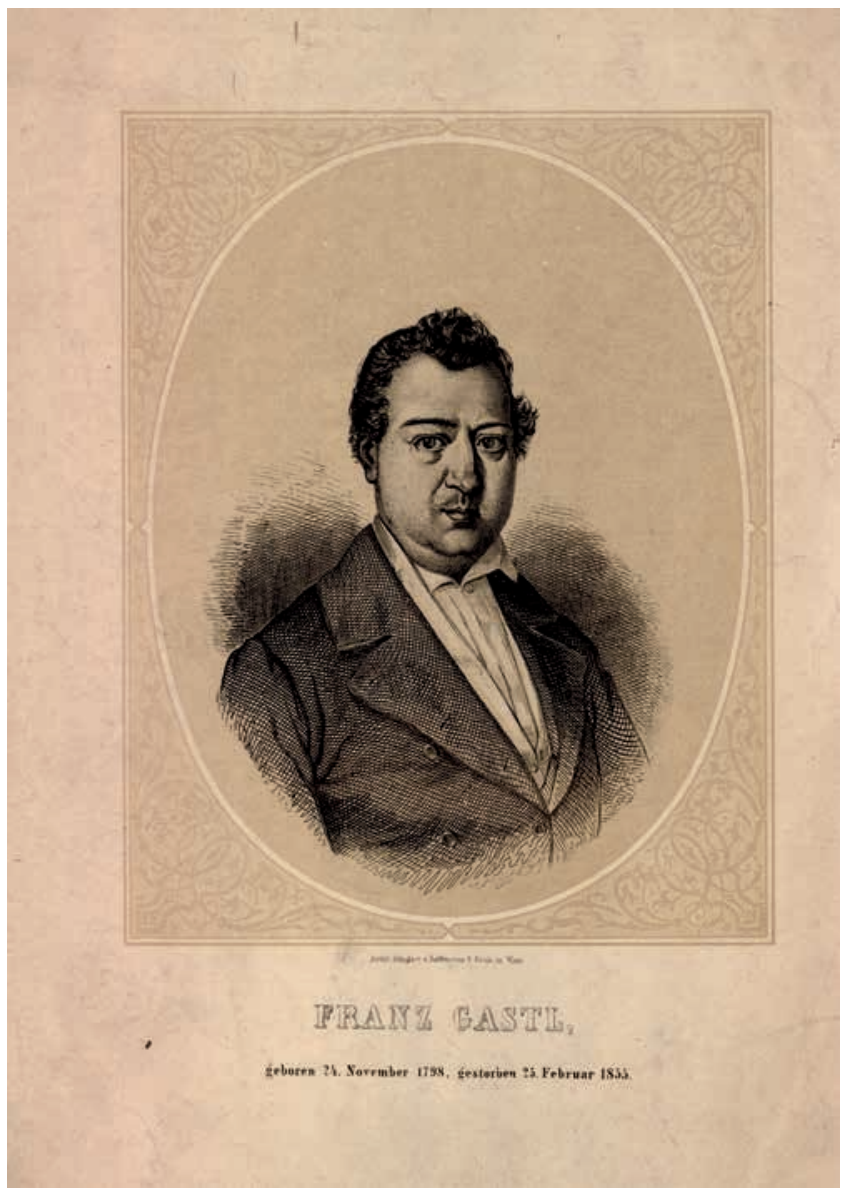

Obr. 1. FRANZ GASTL, geboren 24. November 1798, gestorben 25. Februar 1855. Wien: Artist. lith. Anst. v. Reiffenstein \& Rösch, [1855]. MZK, sign. Skř.2J-0090.853.

tak i olomoucké knihkupectví, které Johann Georg Gastl zakoupil od svého švagra Franze Gärtnera v roce $1799 .^{3}$ Rodinná firma sídlící v centru Brna $v$ dnešní Poštovské ulici 446 a Masarykově ulici $34 \mathrm{v}$ sobě v této době zahrnovala tiskárnu, knihkupectví, obchod s uměleckými předměty, antikvariát nebo sklad knih. ${ }^{4}$ Vedle toho Gastlovi provozovali ještě knihkupectví v Olomouci, které od roku 1821 vedl mladší ze synů Franz Gastl, jemuž bude dále věnována pozornost.

Franz Gastl, který se již od mládí pohyboval v rodinné firmě, se brzy seznámil jak s provozem tiskárny, tak vlastního knihkupectví, které se stalo nejen výkladní skřriní Gastlovy tiskárny, ale protože bylo již od doby svého vzniku navázáno na evropskou knihkupeckou sít’ a nabízelo brněnským, a potažmo i moravským čtenářům tisky vydávané např. v Praze, Vídni nebo Německu, také jedním z center knižního obchodu v českých zemích. Stejně jako jeho starší bratr, Johann Nepomuk Gastl, se také Franz Gastl vyučil knihkupcem. Nejdř́ive pod otcovým a bratrovým dohledem v Brně a poté ve Vídni, kde absolvoval praxi v několika knihkupectvích, např. ve firmě Karla Gerolda. Po vyučení a dosažení dospělosti se měl Franz Gastl podle dohody zapojit do chodu rodinné firmy. ${ }^{5} \mathrm{~V}$ srpnu 1821 mu proto jeho starší bratr pro začátek svěřil vedení olomoucké filiálky Gastlova knihkupectví, kde mu byl k ruce schopný Johann Neugebauer, který se knihkupeckému řemeslu vyučil u Johanna Georga Gastla a od roku 1814 olomoucké knihkupectví prakticky řídil a byl tak plně zasvěcen do jeho provozu. Franzi Gastlovi tak mohl předat řadu cenných rad. ${ }^{6}$ Poté, co bylo jmenování Franze Gastla do čela olomouckého knihkupectví schváleno moravským místodržitelstvím, se ujal jeho správy a od července 1822 se začíná prezentovat jako olomoucký knihkupec. ${ }^{7}$ Převzetí olomouckého knihkupectví Franzem Gastlem neopomněli bratři inzerovat $\mathrm{v}$ novinách vydávaných jejich tiskárnou. Franz Gastl se v oznámení otištěném v Brünner Zeitung zavazuje, že pozvedne úroveň olomouckého knihkupectví, slibuje velké změny a maximální vstřícnost zákazníkům, kteří na pultech jeho knihkupectví naleznou nejen nejmodernější literaturu různých žánrů i jazykového složení, učebnice a odborné texty, periodika, stále oblíbenější muzikálie, ale k dostání zde budou také umělecké předměty, které jejich milovníci zakoupí za nejnižší ceny. ${ }^{8}$

Během svého skoro 10letého působení v čele olomouckého knihkupectví nacházejícího se na Horním náměstí se Franz Gastl skutečně snažil pozvednout jeho úroveň a vybudovat z něj jedno ze čtenářských a kulturních center města. Díky tomu, že byl společně s bratrem Johannem Nepomukem Gastlem navázán na rozsáhlou knihkupeckou sít' s kontakty ve Vídni i v ř́ší, byl schopen zajistit zájemcům tisky z celé Evropy. ${ }^{9}$ Zákazníci tak mohli v olomouckém i brněnském knihkupectví nalézt nejnovější literaturu všech žánrů a Franz Gastl neváhal vycházet vstříc jejich požadavkům. Olomoucké knihkupectví pod jeho vedením zajišt'ovalo také německy i česky tištěné učebnice vydávané Johannem Nepomukem Gastlem, který byl hlavním vydavatelem normální školy na Moravě a ve Slezsku. Gastlovo knihkupectví bylo rovněž napojeno na olomouckou univerzitu, místní

\footnotetext{
Johann Georg Gastl zakoupil olomoucké knihkupectví Franze Gärtnera v roce 1799 za 2000 zlatých. Kupní smlouva, kterou spolu 9. listopadu 1799 uzavřeli, se týkala i jejich budoucí spolupráce spočívající především na vzájemné distribuci knih, nebot' Franz Gärtner v roce 1799 založil knihkupectví v Krakově. MZA, B 14 st., kart. 335, sign. 15/2.

4 ,,399. Johann Nep. Gastl Sattlergasse [...] 446. Gebrüder Gastl Post-oder Obere-Johannesgasse. “Verzeichniss 1818. Více o tiskárně, a především kamenotiskárně Johanna Nepomuka Gastla viz HEILANDOVÁ 2019, s. 312-320.

${ }^{5}$ Na rozdělení pravomocí a fungování rodinné firmy po dobu, než Franz Gastl dosáhne plnoletosti, se bratři dohodli již v době smrti jejich otce. V roce 1816 byla dohoda znovu potvrzena u moravského místodržitelství. MZA, B 14 st., kart. 335, sign. 15/2.

${ }^{6}$ Franz Gastl byl jako olomoucký knihkupec potvrzen dekretem 22516 ze 17. srpna 1821. MZA, B 14 st., kart. 335, sign. 15/2.

7 Od roku 1821 vystupuje jako Franz Gastl, Olmützer Buchhändler.

Buchhandlungs-Anzeige. Mährisch. Ständische Brünner Zeitung. Intelligenzblatt für Mähren. Nro. 204, 27. Juli 1822, s. 1033

9 Knihkupecká obchodní sít bratří Gastlů byla propojená, proto se často v inzerátech dočteme, že nabízená publikace je k dostání u Gastlů v Brně a Olomouci. Mezi knihkupce, s nimiž Gastlovi udržovali kontakty, patřili napřn. vídeňští knihkupci Karl Armbruster, Christian Karl Andre, J. G. Heubner a Thaddäus Weigl, pražská tiskárna Gottlieba Haase nebo Johann Andreas Kienreich ze Štýrského Hradce, který dokonce vydal samostatný 138stránkový katalog své produkce nabízené v knihkupectví Franze Gastla. Vydání katalogu svědčí nejen o kontaktech, ale i o významném postavení, které Gastlovo knihkupectví později zaujímalo v rámci knižního obchodu. KIENREICH 1838.
} 
spolky či zdejší čtenářskou společnost a brzy se stalo jedním z oblíbených míst, kde se potkávali olomoučtí měšt’ané.

Ačkoliv olomoucké knihkupectví pod vedením Franze Gastla vzkvétalo, stále se jednalo pouze o filiálku rodinné firmy sídlící v Brně. Franz Gastl měl podle plánů pobýt v Olomouci pouze určitý čas, během něhož se měl seznámit s chodem knihkupeckého obchodu, fungováním knihkupecké obchodní sítě, na niž byli Gastlovi navázáni, nebo poznat čtenářskou obec, naučit se komunikovat se zákazníky a rozpoznat jejich vkus a požadavky, které by mohly být reflektovány $\mathrm{v}$ edičním plánu rodinné tiskárny. $\mathrm{V}$ menším provozu měl tak získat náležitou praxi, kterou mohl později uplatnit $\mathrm{v}$ brněnské rodinné firmě. $\mathrm{K}$ odchodu z olomoucké filiálky se Franz Gastl po dohodě se svým bratrem rozhodl v roce 1829. V průběhu roku se postupně přestěhoval do Brna, kde měl podle smlouvy z 19. ledna 1829 převzít správu části vzkvétajícího a stále se rozšiřujícího rodinného podniku. ${ }^{10}$ Vedení olomoucké filiálky bratř̌i přenechali Johannu Neugebauerovi, který od nich knihkupectví později odkoupil. ${ }^{11}$ Samotná brněnská firma byla rozdělena mezi bratry tak, že si Jan Nepomuk Gastl ponechal vedení tiskárny, u ní se nacházející litografické dílny ${ }^{12}$ a vydavatelství normální školy a Franz Gastl stanul nejen v čele brněnského knihkupectví, ale zároveň se ujal i vedení vydavatelství a získal tak př́mý vliv na ediční plán tiskárny. ${ }^{13}$ Předávání provozů probíhalo postupně a jistě se zpomalilo i kvůli nutné administrativě, kdy veškeré změny musela schválit městská rada, místodržitelství i policejní ředitelství. Ačkoliv již od začátku roku 1829 pobýval Franz Gastl stále častěji v Brně, až do záŕí působil zároveň také v Olomouci, kde částečně dohlížel na chod knihkupectví, ale především zajišstoval jeho plynulé předání Johannu Neugebauerovi. K oficiální změně majitelů, která se projevila i navenek, došlo až na začátku října, kdy byli s novou situací seznámeni také zákazníci, a to prostřednictvím oznámení otištěného 17. října 1829 v př́loze Intelligenzblatt für Mähren. Franz Gastl v něm čtenářum a svým potencionálním zákazníkům sděluje, že se ujímá brněnského obchodu, který povede $\mathrm{k}$ jejich největší spokojenosti. Slibuje širokou nabídku kvalitních tisků a plynulé navázání na věhlasnou knihkupeckou tradici, kterou v Brně jeho rodina již 45 let buduje. ${ }^{14}$ Jeho bratr, Johann Nepomuk Gastl, na stejné straně pak poměrně stroze oznámil, že bude i nadále pokračovat $\mathrm{v}$ tiskařských aktivitách a $\mathrm{v}$ jeho produkci zákazníci naleznou či si mohou objednat nedávno zakoupeným písmem a na kvalitním papíré tištěná díla. ${ }^{15}$ Předání olomoucké filiálky Johannu Neugebauerovi pak bylo inzerováno ve stejném periodiku dne 8 . listopadu 1829. ${ }^{16}$ Od poloviny ř́ijna 1829 již obě firmy vystupují pod jmény svých nových majitelů, i když ještě i v roce 1830 je $\mathrm{v}$ některých inzerátech pro přehlednost uváděn i odkaz na původní stav. Názorně je to napřs. vidět $\mathrm{v}$ inzerátu k prodeji výherních losů uveřejněném v dubnu roku 1830: „Lose a 5 fl. C.M. samt Gewinst-Freylosen sind bey Franz (vormahls J. G.) Gastl in Brünn und bey Johann Neugebauer (vormahls Franz Gastl) in Olmütz zu haben. "17

Franz Gastl po svém přesunu do Brna plynule navázal na své olomoucké aktivity. V dobře zásobeném knihkupectví nacházejícím se na rohu dnešní Masarykovy ulice byla k dostání odborná i populární literatura různých žánrů, periodický tisk, hudebniny nebo umělecké předměty. Díky tomu, že Franz Gastl již 10 let působil v knihkupeckém obchodě a přišel se zákazníky úzce do styku, znal jejich vkus a mohl na něj svou nabídkou bezprostředně reagovat. Protože byl dlouhodobě navázaný na širokou evropskou knihkupeckou sít', byl bez jakýchkoliv průtahů schopný opatřit aktuální dostupnou a cenzurně schválenou literaturu. Stejně jako tomu bylo v Olomouci, také v Brně usiloval o to, aby se jeho knihkupectví stalo kulturním a čtenářským centrem. I proto u něj v červnu 1831 založil první otevřenou půjčovnu knih. Nedlouho po jejím otevření vydal v rámci její propagace také pětisvazkový katalog evidující 3023 často i několikasvazkových děl tištěných v němčině, latině, francouzštině nebo italštině. ${ }^{18}$ Franz Gastl fond půjčovny průběžně doplňoval a během let několikanásobně rozš̌iřil. ${ }^{19}$ Abonenti si za roční poplatek osm zlatých, k němuž byla připočtena vratná kauce tř̌ zlaté, mohli denně půjčovat jednu

\footnotetext{
${ }^{10}$ MZA, B 14 st., kart. 335, sign. 15/2.

${ }^{11} \mathrm{~K}$ rozhodnutí, že bude olomoucké knihkupectví přenecháno Johannu Neugebauerovi, došlo 20. února 1829. Johann Neugebauer měl poté př́slušným úřadům doložit nejen svoji praxi, bezúhonnost, ale také na základě nařízení Knihkupeckého patentu z roku 1806 doložit kapitál, který zabezpečí chod knihkupectví. MZA, B 14 st., kart. 335, sign. 15/2.

${ }^{12}$ Johannu Nepomukovi Gastlovi bylo dne 18. června 1824 uděleno povolení k založení litografické dílny, jejíž produkce měla rozš́řrit nabídku knihtiskárny. Provoz litografické dílny byl ale ukončen již v roce 1829. ,,Johann Gastl. Buchdrucker, Buch- und Kunsthändler zur lithographen befrucht mit Präs dekr. 18. Juni 1824 z. 14707/Jun. Z. 174/104. Verzichtgeleistet auf der lithogr. Am J. 1829. “ MZA, B 26, kniha 843.

13 ,,Willens auf Grunde dieses allerhöchsten Patents meine hiesige Buchhandlung nebst dem Waarenlager unter den in diesem Gesetz $\$ 8$ bestimmenten Modalitäten an meinen mitgefertigten Bruder Franz Gastl, Buchhändler zu Ollmütz abzutreten, und mich der Buchdruckerey und der Lithographie zu widmen, und den Verlag, dann Verschleiß der Normalschulbücher wie bisher fortan zu besorgen. “ MZA, B 14 st., kart. 335, sign. 15/2.

${ }^{14}$ „Ich gebe mir die Ehre hiedurch anzuzeigen: daß ich die mir von meinem Bruder Johann Gastl übertragene, und unter der Firma: Joh. Georg Gastl allhier bestandene Buch-, Kunst- und Musikalienhandlung, sammt dem sämmtlichen Verlage und den Verlags-Rechten, mit allen Activa und Passiva übernommen habe, und daß ich diese unter der untenstehenden Firma ganz in der bisherige Ordnung ungestört fortsetzen werde. " Dank und Empfehlung. Mährisch. Ständische Brünner Zeitung. Intelligenzblatt für Mähren. Nro. 286, 17. Oktober 1829, s. 1821.

${ }^{15}$, ,... bringe ich zugleich zur gefälligen Kenntniß: daß ich die Buchdruckerey, die Lithographie, so wie auch den Verlag der sämtlichen Normalschulbücher in dem bisherigen ganzen Umfange unter meinem Namen fortführen werde. "Dank und Empfehlung. Mährisch. Ständische Brünner Zeitung. Intelligenzblatt für Mähren. Nro. 286, 17. Oktober 1829, s. 1821.

${ }^{16}$ Buchhandlungs-Empfehlung und Dank. Mährisch. Ständische Brünner Zeitung. Intelligenzblatt für Mähren. Nro. 308, 8. November 1829, s. 1953.

${ }^{17}$ Mährisch. Ständische Brünner Zeitung. Nro. 101, 12. April 1830, s. 542.

${ }^{18}$ Knihy byly v půjčovně roztříděny podle oborů do 22 tematických celků zahrnujících např. filozofii, teologii, historii, právo, obchod, lékařství, prírodovědu nebo matematiku a stavitelství. Nechyběl ani oddíl, v němž se nacházely př́ručky, cestopisy, divadelní hry, romány, ženská literatura, německá poezie a próza vydávaná v souborných edicích nebo francouzská a italská literatura. Vydáním katalogu půjčovnu knih Franz Gastl zpřístupnil také zájemcům mimo Brno, kteří si z ní mohli půjčení knih objednat poštou. Bücher-Verzeichniß 1831-1833.

${ }^{19} \mathrm{~V}$ době jeho smrti v roce 1855 se v půjčovně nacházelo bezmála 20000 děl. MZA, B 14 st., kart. 336, sign. 15/2, fol. 550v.
} 


\section{ă \\ be $\mathrm{I}$}

öf f $\mathfrak{e} \mathfrak{n} \mathfrak{l} \mathfrak{i} d \mathfrak{d} \mathfrak{n}$

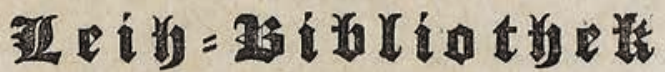

D

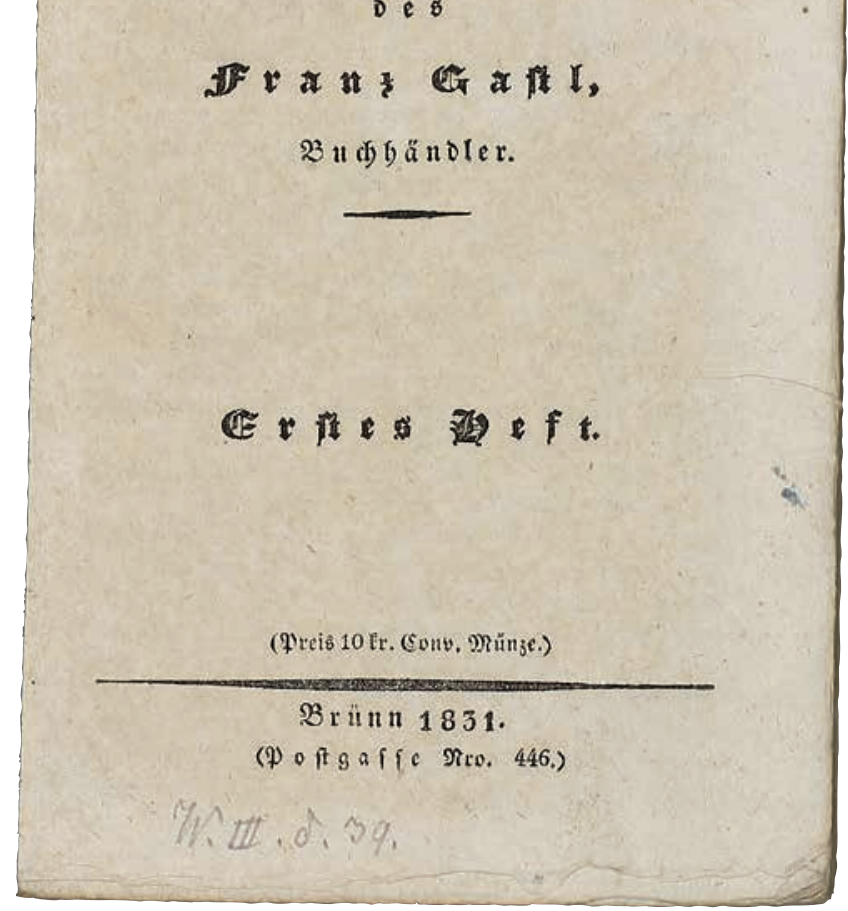

Obr. 2. Titulní list katalogu půjčovny knih. Bücher-Verzeichniß der öffentlichen Leih-Bibliothek des Franz Gastl, Buchhändler. Erstes Heft. Brünn: Franz Gastl, 1831. Knihovna benediktinského opatství Rajhrad, sign. R - X. I. aa. 5.

knihu, kterou měli k dispozici, dokud ji nepřečetli, nejdéle však po dobu jednoho měsíce. Otvírací hodiny půjčovny byly 9-12 a $14-18$ hodin..$^{20}$

Vedle vlastního knihkupectví získal Franz Gastl v roce 1829 na starost také vydavatelství, které bylo navázáno na tiskárnu Johanna Nepomuka Gastla, jejíž prioritou byl především tisk materiálů pro potřeby normální školy a vydávání úředních a akcidenčních tisků. Franz Gastl, který se po svém př́ichodu do Brna s plným nasazením věnoval knižnímu obchodu, se zajímal i o provoz vlastní tiskárny. Aby do tiskařského umění blíže pronikl, neváhal se mu v tiskárně svého bratra v letech 1829-1832 vyučit. Později během bratrovy stále častější nepřítomnosti ho nejednou zastupoval a úspěšně tiskárnu vedl, čímž prokázal nejen potřebnou odbornost, ale i svoji schopnost provoz tiskárny samostatně rídit. Kolem poloviny 30. let se Franz Gastl plně zapojil i do vydavatelské činnosti a pravděpodobně i z jeho iniciativy se vedle učebnic patř̌icích $\mathrm{k}$ běžné produkci Gastlovy tiskárny začínají $\mathrm{v}$ edičním plánu objevovat také př́ležitostné tisky, teologická díla, biblické a liturgické texty a postupně přibývají i antičtí klasikové nebo současní německy písííi autoři. ${ }^{21}$ Právě u těchto děl vydávaných většinou $\mathrm{v}$ druhé polovině 30 . let se často v impresu objevuje jméno Franze Gastla.

Brněnská spolupráce obou bratrů však netrvala dlouho, nebot' v roce 1836 se Johann Nepomuk Gastl rozhodl svému bratrovi tiskárnu prodat a plně se věnovat obchodu. ${ }^{22} \mathrm{~V}$ průběhu roku 1838 byly vyř́zeny veškeré právní náležitosti a již v následujícím roce se Franz Gastl stal jediným majitelem firmy zahrnující v sobě knihkupectví, vydavatelství, obchod s hudebninami a uměleckými předměty, půjčovnu knih, antikvariát, vydavatelství normální školy, tiskárnu a původní Kohlennederovu písmolijnu, kterou Gastlovi přikoupili k tiskárně v roce 1834 .

Tiskárna pod vedením Franze Gastla, který plynule navázal na dosavadní bratrovy aktivity a mnohonásobně je rozšíríl, prosperovala a vydobyla si výsadní postavení na moravském knižním trhu. V roce 1836 získal Franz Gastl čestné právo hlavního nakladatele a tiskaře normální školy, které si podržel až do roku 1853, kdy přešlo na c. k. tiskárnu. Díky tomuto privilegiu byly také v jeho tiskárně vydávány slabikáŕe, čítanky, učebnice pro gymnázia, normální i odborné školy, školní výroční zprávy, nebo nejrůznější výukový materiál. Právě učebnice tištěné v německé i české jazykové mutaci tvořily významnou část gastlovské produkce již od založení tiskárny na počátku 19. století. Vedle tisků pro školní potřebu byly v tiskárně Franze Gastla vydávány nejrůznější př́ležitostné tisky nebo teologická a duchovní literatura. Tiskárna se oproti předchozí praxi více zaměřila i na vydávání literatury pro nejširší lidové vrstvy a do edičního plánu byly zahrnuty německy i česky tištěné modlitby, písně, krátká rozjímání, kancionály nebo nejrůznější pojednání. Významné místo v produkci tiskárny začala zaujímat také topografická a historická díla. Díky tomu, že Franz Gastl aktivně spolupracoval s brněnskými spolky, v řadě z nich byl též sám členem, vyšlo $v$ jeho tiskárně množstvích děl vzniklých z jejich iniciativy nebo sepsaných jejich členy. ${ }^{23}$ Ve známost vstoupil rovněž jako tiskař Brünner Zeitung vydávaného v letech 1819-1848, časopisu Mährischer Korrespondent, kalendáře Bote aus Mähren tišstěného v české i německé jazykové variantě a autorských kalendářù Karla Josefa Jurendeho Jurende's Mährischer Wanderer a Jurende's Vaterländischer Pilger in dem Kaiserstaate Oesterreichs, jež se staly vlajkovou lodí Gastlova nakladatelství.

\footnotetext{
${ }^{20}$ Bücher-Verzeichniß 1831.

${ }^{21}$ Matutinum 1837; Officium 1836; HORATIUS 1830; RATZER 1837.

${ }^{22}$ „Franz Gastl als Besitzer des staedtischen verkäuflichen Buchdrukerey Befugnißes N1. aus gezeichnet, welches Besitzrecht für ihr auf Grund des mit seinem Bruder Johann N. Gastl unterm 1. Dezember 1836 geschloßenen Kaufkontrakts in Folge Magistrats verordnungen: 31 . August 1838 Z 8285 Jud: in dem Normalwerthe von 4000 fr. am 12. September 1838 vorgeschrieben wurde. " MZA, B 14 st., kart. 335, sign. 15/2, fasc. $23927 / 2496$.

${ }^{23}$ Díky spolupráci Franze Gastla s brněnskými spolky byly v jeho tiskárně vydávána spolková statuta, výroční zprávy nebo díla vycházející z jejich činnosti, nejrůznější prríručky a instrukce.
} 
Významné místo v Gastlově produkci představoval také tisk sbírek moravských zákonů, vládních věstníků, právních a úředních tisků. ${ }^{24} \mathrm{~S}$ moravským místodržitelstvím a správními úřady, jejichž zakázky byly pro brněnské tiskaře často klíčové, spolupracoval Franz Gastl již od samého počátku. Od konce 30. let 19. století vydával pro potřeby městských zastupitelstev, správních nebo vojenských úřadů sídlících na Moravě nejrůznější formuláře, drobnější tisky nebo příručky. Kromě toho byl i jedním z dodavatelů psacího i tiskového papíru. ${ }^{25} \mathrm{O}$ řadu zakázek se ale musel již od počátku dělit s dalšími brněnskými tiskaři, at' již s tiskárnou dědiců Rudolfa Rohrera, nebo tiskárnou a kamenotiskárnou Prokopa Fritsche, jež vlastnila v letech 1829-1844 monopol na tiskařské a litografické práce pro moravské místodržitelství, o které měl Franz Gastl eminentní zájem. Díky kontaktům a přibývajícím zakázkám pro státní sektor se Gastlovi postupně podařilo upadající Fritschovu tiskárnu vytlačit. Již roku 1839 např. uzavřel s moravským místodržitelstvím smlouvu na tisk Schematismů a postupně pro jeho potřeby začal vydávat zprávy, instrukce nebo akcidenční a administrativní tisky. ${ }^{26}$ Samotné privilegium na knihtiskařské a litografické zakázky pro moravské místodržitelství a správní úřady se Gastlovi podařilo získat v roce 1844 a podržel si ho až do své smrti. ${ }^{27}$

Při realizaci zakázek státních úřadů využíval Franz Gastl vedle knihtisku také kamenotisk, nebot' současně s koupí tiskárny se rozhodl také obnovit kamenotiskárnu, která při tiskárně fungovala v letech 1824-1829. V žádosti z 1. března 1839 zaslané moravskému místodržitelství Franz Gastl poukazuje nejen na to, že se u tiskárny jeho bratra již dříve kamenotiskárna nacházela a on zde měl možnost litografickou práci poznat, ale také na skutečnost, že jako knihkupec a obchodník s uměním a hudebninami s litografickými dílnami často spolupracoval a i díky svým kontaktům je schopen zajistit provoz obnovené kamenotiskárny. ${ }^{28}$ Neopomněl ani upozornit, že v Brně v této době působí pouze kamenotiskárny patřící Rudolfu Rohrerovi a Johannu Baptistovi
Trasslerovi a založení komerční kamenotiskárny spojené s gastlovskou tiskárnou a zaměřující se především na administrativní a akcidenční tisky a př́ípadnou realizaci ilustrací objevujících se v Gastlem vydávaných učebnicích nebo odborných a populárních dílech by je existenčně neohrozilo, a zákazníci by širší nabídku litografických tisků a začlenění litografických obrazových př́loh do publikací jistě uvítali. ${ }^{29}$ Moravské místodržitelství i policejní ředitelství vyslyšelo Gastlovu žádost a povolení k založení kamenotiskárny mu bylo uděleno již 16 . července $1839 .^{30}$

Jak již bylo řečeno, kamenotiskárna Franze Gastla neměla nikdy umělecké ambice, vznikla jako součást tiskárny, což dokládají také její první realizace, mezi kterými se vedle četných akcidenčních tisků a tiskopisů nacházejí také litografické prŕllohy, ilustrace a později i knižní obálky. Mezi litografickými přílohami, s nimiž se v tiscích Franze Gastla setkáme, převažují technické nákresy nebo plány, u nichž šlo především o přesnou, názornou a detailní kresbu než o umělecké ztvárnění. Např. v roce 1839 tiskárna Franze Gastla vydala publikaci Aloise Diebla s popisem mlátičky a drtičky provázenou litografickými př́lohami s nákresy strojů, které Alois Diebl ve svém spise popsal a jejichž nákresy sám zhotovil. ${ }^{31}$ Do litografické podoby je poté převedl Johann Lichtenberg, který v Gastlově kamenotiskárně působil v letech 1839-1840 a jehož litografie se vyznačují jemnou a precizní kresbou. ${ }^{32}$ Litografie s přesnými technickými nákresy Johanna Lichtenberga provází i publikaci Nikolause Gáala de Gyula Anleitung zur Herstellung zweckmässiger Abtritte, Cloaken, Kanäle etc. etc. ${ }^{33}$ Nesignované litografické prrílohy se objevují např. v díle Karla Benesche popisujícím rosické panství ${ }^{34}$ nebo v učebnici Aloise Kürschnera Ponaučenj pro př́delnj sskoly. ${ }^{35}$ Ačkoliv se s litografickými př́lohami v publikacích vydávaných Franzem Gastlem setkáme po celou dobu působení litografické dílny, zůstávají v menšině a v produkci převažují spíše texty ilustrované mědirytinami či díla bez obrazového doprovodu.

${ }^{24}$ Franz Gastl vydával např. Provinzial-Gesetzsammlung für Mähren und Schlesien, tištěné v letech 1819-1848, či Landesgesetz-und Regierungsblatt a jeho českou mutaci Věstník vlády zemské pro Markrabství Moravské, vydávané od roku 1850.

${ }^{25}$ Tiskárna Franze Gastla tiskla formuláře a rubriky pro potřebu úřadů sídlících např. v Brně, Boskovicích, Znojmě, Slavkově nebo Mikulově. MZA, B 14 st., kart. 325.

${ }^{26}$ MZA, B 14 st., kart. 325, sign. 15/2.

${ }^{27}$ Franz Gastl s moravským místodržitelstvím uzavřel šestiletý kontrakt na tiskařské a litografické práce realizované od 1. listopadu 1844 do konce roku 1850. MZA, B 14 st., kart. 325, sign. 15/2, fasc. 44062/5970. Po uplynutí této doby mu byla smlouva několikrát obnovena.

${ }^{28}$,....dann wie ihm von seinem Bruder Johann Gastl als früher Innhaber einer lithographischen Anstalt in dem angeführten Zeugniße bestättiget wird, hat er sich mit der Buchdrukerey auch eine gründliche Kentniß der Lythographie eigen gemacht, und sich zur selbstständigen Leitung derselben vollkommen gualifiert. "MZA, B 14 st., kart. 335, sign. 15/2.

29 , , da hier gegenwärtig nur zwey Steindruckereyen, jene des Rudolph Rohrer u. J. G. Traßler bestehen, u. bey dem steigenden Bedarf lithographirten Arbeiten für Beförden u. das Publicum, die Concurenz eines driten Lithographien allerdings willkommen seyn muß. " MZA, B 14 st., kart. 335 , sign. 15/2. Otázkou je, proč Franz Gastl ve své žádosti neuvedl v Brně rovněž působící tiskárnu a kamenotiskárnu Prokopa Fritsche, jejíž produkce byla zaměřena především na vydávání administrativních a akcidenčních tisků, jejichž kamenotisk Gastl plánoval.

${ }^{30}$ MZA, B 14 st., kart. 335, sign. 15/2, fasc. 23927/2496.; MZA, B 26, kniha 843. Více o kamenotiskárně Franze Gastla viz HEILANDOVÁ 2019, s. 320-332.

${ }^{31}$ Publikaci doprovází čtyři litografické př́lohy: Dreschmaschine zu Studlow auf dem Gute Křetin.; Dresch-Machine im Orte Křetin auf dem Gute

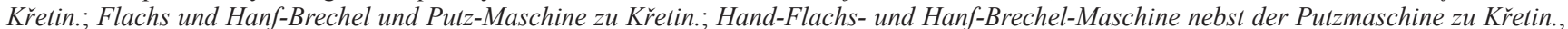
které mají autorské označení Aufgenommen und gezeichnet von Alois Dieb. Steind. v. F. Gastl in Brünn. Joh. Lichtenberg lith. DIEBL 1839.

${ }^{32}$ Brněnský litograf Johann Lichtenberg před nástupem do kamenotiskárny Franze Gastla působil v kamenotiskárně jeho bratra Johanna Nepomuka Gastla nebo v kamenotiskárně Prokopa Fritsche. Poté, co mu byla zamítnuta žádost o udělení litografické koncese, kterou si podal v době, kdy byl zaměstnán v Gastlově kamenotiskárně, nastoupil v roce 1841 jako litograf v kamenotiskárně Johanna Baptisty Trasslera a v jejím čele stál až do př́chodu Martina Perny. MZA, B 14 st., kart. 333, sign. 15/2, ff. 51-85.

${ }^{33}$ Litografické př́lohy jsou signované Steind. v. F. Gastl in Brünn. Joh. Lichtenberg lith. GÁAL DE GYULA 1841.

${ }^{34}$ Beschreibung 1841.

${ }^{35}$ KÜRSCHNER 1849 


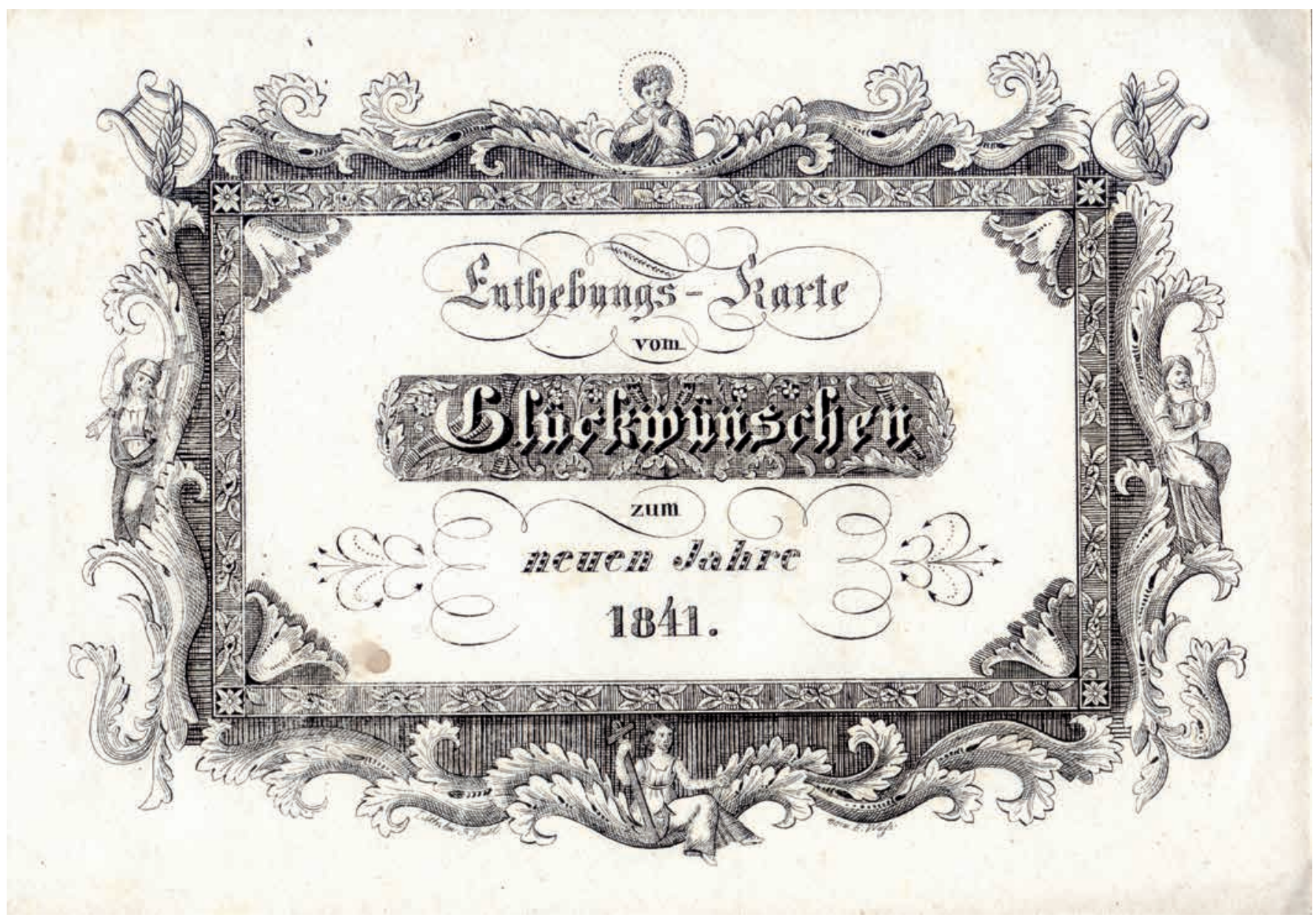

Obr. 3. Novoročenka Franze Gastla na rok 1841. WEIS, Eduard. Enthebungs- Karte vom Glückwünschen zum neuen Jahre 1841. [Brünn: Franz Gastl, 1840]. MZK, sign. Skř.1O-1156.036.

Primární specializací kamenotiskárny Franze Gastla se tak stal tisk tiskopisů, administrativních a zejména akcidenčních tisko̊, jejichž obliba v průběhu 19. století prudce vzrůstala, a právě litografie zde našla své obrovské uplatnění. Mezi realizacemi Gastlovy kamenotiskárny vynikaly nejrůznější vstupenky, pozvánky, členské karty, ${ }^{36}$ blahoprání a novoročenky. Zejména novoročenky vytvořené pro samotného Franze Gastla zaujmou svojí podobou, která byla bud' kaligraficky řešená, či obrazově reflektovala módní trendy. ${ }^{37}$
K dalším akcidenčním tiskům, s nimiž se můžeme v produkci kamenotiskárny setkat, patřily např. pilnostenky, učňovské i mistrovské listy nebo výukový materiál určený pro základní i střední školy, který doplňoval učebnice, na jejichž vydávání měla tiskárna Franze Gastla na Moravě a ve Slezsku až do roku 1853 monopol. ${ }^{38}$ Již ve 30 . letech se Gastlovi podařilo uzavř́t řadu smluv na tiskařské a litografické práce pro brněnské úřady, vojenské velitelství i další úřady státní správy sídlící nejen v Brně, ale na území celé

\footnotetext{
${ }^{36}$ AUFNAHMS-KARTE ... als Mitglied der vierten Versammlung deutscher Land- und Fortwirthe. Diese Karte gilt als Autenthaltsschein, als Eintrittskarte zu den Sitzungen und als Anweisung zur Erhebung eines Exemplars der zu vertheilenden Drucksachen. Gesehen für Kassejournal. Den statutenmässigen Geld Beitrag von 6 fl. C.M. verbucht. Steind. v. Fr. Gastl in Brünn. Lichtenberg lith. [1840]. MZA, E 6, kart. 110, inv. č. 1673, sign. D.c.2, fol. 199.

${ }^{37}$ Dekorativně je např. pojatá novoročenka na rok 1841, která má podobu dekorativního rámce s textem. WEIS, Eduard. Enthebungs-Karte vom Glückwünschen zum neuen Jahre 1841. Lith. bei F. Gastl von E. Weiss. S obrazovou novoročenkou Franze Gastla se můžeme setkat hned následující rok. WEIS, Eduard. Enthebungs-Karte vom Glückwünschen für 1842. Franz Gastl's Lithographie. lith. Ed. Weiss.

${ }^{38}$ Široká nabídka Gastlovy kamenotiskárny byla často prezentována prostřednictvím inzerátů otištěných v denním tisku. „,Aus Franz Gastl’s Steindruckerei in Brünn sind in obengenannter Buchhandlung zu haben: Billeten, schwarze, 100 Stück $36 \mathrm{kr}$. CM.; Fleißzetteln für Schüler, 21 Stück auf 1 Bogen mit schön verzeirter Einfassung, $6 \mathrm{kr}$. WW.; Fleißzetteln von feinerer Art, mit Verzierungen und Figuren auf Satinetpapier, das Stück 6 kr. WW.; Jägerlehrbrief auf feinen Velinpapier, das Stück 24 kr. CM.; Lehrbriefe, das Stück 6 kr. CM.; Meisterbriefe auf feinem Velinpapier, das Stück 36 kr.; Tuchmuster, verschiedener Art, der Bogen 6 kr. WW.; Uebersicht, summarische, über den Zustand der Volksschulen, auf Großregal-Schreibpapier, 1 1⁄2 Bogen, zusammen geheftet, 8 kr. CM.; Wechselbriefe auf feinem Velinpapier, das Stück 3 kr., 100 Stück 4 fl. $10 \mathrm{kr}$. WW. In oben erwähnter Steindruckerei weren alle in das Bereich dieses Kunstzweiges einschlagenden Schrift-, Zeichnungs- und andere Gegenstände in dem neuesten Geschmacke mit aller Pünctlichkeit und zu möglichst billigen Preisen ausgeführt. "Mährisch. Ständische Brünner Zeitung. Intelligenzblatt für Mähren. Nro. 248. Freitag den 9. October 1842, s. 2014.
} 
Moravy. ${ }^{39}$ Pravidelné litografické i tiskařské práce pro státní správu a moravské úřady představovaly významnou položku v produkci Gastlova podniku. Mezi realizacemi se objevují např. formuláře, koncepty, hlavičkové papíry nebo jednolisty určené pro potřebu městských i státních úřadů. ${ }^{40}$ Protože byla kamenotiskárna již od svého založení součástí tiskárny, byly většinou tyto práce účtovány dohromady, nebo byly zahrnuty pod souhrnný název tiskařské a litografické práce Druckarbeiten und Lithographien, př́padně Buch- und Steindrucken. ${ }^{41}$

Podnik Franze Gastla po celou dobu jeho života prosperoval a od doby, kdy Franz Gastl nastoupil do jeho vedení, se mnohonásobně zvětšil. Zakázky pro školský úřad a státní správu mu zajistily pravidelný a stálý příjem, který Franz Gastl neváhal investovat také do modernizace provozu či aktualizace typografického fondu, díky čemuž mohla tiskárna kvalitou svého tisku i použitou typografií směle konkurovat vídeňským i pražským firmám. Z dobových pramenů a literatury víme, že se v 50 . letech v tiskárně nacházelo 12 původních dřevěných lisů, jeden Stanhopeho železný ruční lis, dva rychlolisy, tři moderní ruční lisy nebo Satinir lis využívaný pro knižní vazbu. Litografická dílna pak byla vybavena dvěma litografickými lisy. ${ }^{42}$, $K$ roku 1853 zaměstnávala knihtiskárna a kamenotiskárna Franze Gastla jak v knihtisku, tak pri lití písma a litografiich 48 osob, z toho při lití pisma, které bylo do té doby téměr výlučně zaméřeno na vlastní provoz, jedenáct lidi. V knihtiskárně zde pracovaly dva velké rychlolisy, tři obyčejné knihtiskařské lisy a jeden satinační stroj, který dodával papíru lesk, a během poslednich čtyř let byla tiskárna opatřena plně novými a nejmodernějšími druhy písma. "43 Jak je z předchozích slov patrné, Franz Gastl během svého působení v čele rodinné firmy podnik nejen rozšíriil, ale také zmodernizoval a vytvořil z něj jedno z nejvýznamnějších a nejvýraznějších moravských polygrafických center. Ačkoliv ke konci života Franz Gastl nebyl již zcela zdráv, trpěl vodnatostí a nemocí jater, nepolevil ve své práci a s plným nasazením a neutuchajícím nadšením se věnoval správě rodinné firmy a dohlížel na její provoz. I kvůli horšícímu se zdraví ale začal do vedení podniku stále více zasvěcovat i svého syna Georga, který ho postupně v řadě funkcí zastoupil a v budoucnu se stal jeho nástupcem.

Franz Gastl zemřel uprostřed noci na 25. února $1855 .{ }^{44}$ V nekrologu uveřejněném v kalendáři Posel morawský se můžeme dočíst nejen podrobnosti týkající se konce jeho života, ale také několik slov týkajících se jeho charakteru. „Frantissek Gastl byl smýsslenjm a gednánjm rozssafný muž, obeznalý podnikatel, prawý wlastenec a úd rodnjho města. Při každé přiležitosti neopominul co prawý lidmil, chudé podporowati. Při tom byl pln pokory a newychwalowal swé činy; mnohé tiskarské práce podniknul z lásky k chudým nežádage za ně žádné záplaty, za čež mu mnohé úrednj pochwala udélena byla. Gjm tedy pozbyla wlast ctihodného muže. "45

Z manželství s Annou Aloisií Paulinou (22. 6. 1813 6. 2. 1886), s níž se oženil v roce 1831 , se narodilo šest dětí, z nichž ho čtyřri přežily. ${ }^{46}$ Rodinný podnik po jeho smrti převzal syn Georg Gastl, který již od raného dětství v tiskárně pracoval a učil se tiskařskému umění, a mohl tak plynule navázat na otcovy aktivity. ${ }^{47}$ Firma, jejíhož vedení se Georg Gastl v roce 1855 ujal, zahrnovala tiskárnu, v níž se nacházely dva rychlolisy a čtyři běžné ruční lisy, písmolijnu, litografickou dílnu, knihkupectví a hojně navštěvovanou

\footnotetext{
${ }^{39}$ Úřední zakázky bohužel nejsou blíže specifikované, většinou je zde uvedené, že se jedná o položky za tiskařské a litografické práce, autografie, dodání tisků, blanketů nebo předtištěného či bílého papíru. Např. ve vyúčtování z roku 1850 se dočteme ,ü̈ber die an die $k$. $k$. Kreisregierung seit Iten Jäner bis Ende Oktober 1850 gelieferten authographischen Arbeiten und Lithographien sind und zwar: der Conto des Buchdruckers Franz Gastl auf $60 \mathrm{fr} .35$ 1/4 xr. “. MZA, B 14 st., kart. 324, sign. 15, fol. 538.

40 , 1.) An die K.K. Guberniel-Expedits-Direkzion. 2.) An das K. K. P. Hauptzahlamt. 3.) An das Olmüzer, 4.) An das Znaimer, 6.) An das Iglauer, 7.) An den brünner Magistrat... "MZA, B 14 st., kart. 324, sign. 15, fol. 1548.

${ }^{41}$ Např. ,, Buchdrucker Franz Gastl für die von ihm zum Gebrauche diese K. K. Guberniums im 3ten Militär Quartale 1846 gelieferten Buch- und Steindruckarbeiten den gemäß des beliegenden Buchhalterischen Ausweises entfallenden Verdienstbetrag von Sechhundert fünfzig Gulden 45 3/4 xr. C.M. “ MZA, B 14 st., kart. 323, sign. 15, fol. 5.

42 „Die Gastl'sche Druckerei ist in der Art eingerichtet, um allen Anforderungen entsprechen zu können; sie besaß vordem 12 Holz- und 1 StanhopePresse. [...] Die lithographische Anstalt beschäftigte 2 Pressen. Der Druckerei stand der Faktor Johann Schwarz vor. 1847 übernahm der jetzige Faktor Ignaz Friedl die technische Leitung der typographischen Anstalt. Es werden daselbst gegenwärtig sowohl in der Buchdruckerei, als Schriftgießerei, bisher fast ausschließlich allein für das eigene Geschäft, 11 Individuen verwendet werden, die Buchdruckerei enthält 2 große Schnellpressen, 3 gewöhnliche Buchdruckpressen und eine Satinirpresse und lieferte seit ungefähr 4 Jahren, seit welcher Zeit sie vollständig neu mit den modernsten Schriftsorten versehen wurde, mehre Werke verschiedenen Inhalts... “ELVERT 1854, s. 112-113.

${ }^{43}$ JANÁK 1987, s. 46.

${ }^{4}$ „, In der Nacht von 24. zum 25. d. um 12 1/4 Uhr ist hier Herr Franz de Paula Gastl, Buchdruckereibesitzer und vieljähriger Verleger der ,Brünner Zeitung', Inhaber einer öffentlichen Leihbibliothek ec., Bürger von Brünn, Realitätenbesitzer ec., in das bessere Jenseits abgeschieden, seine Familie in tieffter Trauer um den ihr durch des Todes Hand zu früh Entriffenen zurücklassend. Die Beerdigung wird Dienstag um 4 Uhr Nachmittags stattfinden. “ Neuigkeiten. Jahrg. V. Nro. 57. Montag den 26. Februar 1855.

${ }^{45}$ Frantissek Gastl. Krátký životopis. In: Posel Morawský aneb domácj, měsst’anský a rolnický Kalendáŕ pro Morawany, Čechy a Slowáky na rok přstupný po narozenj Pána Krista 1856. Dvacátý ročník. Brno [1855], s. 49.

${ }^{46}$ Franz Gastl se v roce 1831 oženil s Annou Aloisií Paulinou (22. 6. 1813 Brno - 6. 2. 1886 Brno), dcerou Franze Illeka/Jileka, měštana a majitele práva vinného výčepu v Brně. Společně měli šest dětí, z nichž syn Georg Johann Franz Gastl (narozený 30. 9. 1834 Brno) po otcově smrti převzal vedení rodinné firmy. SMUTNÝ 2012, s. 124.

47 ,Wie der hohen k: $k$ : Statthalterei ohnehin bekannt, habe ich das verkünftige Buchdruckereibefugniß als Erbe nach meinem in Jahre 1855 verstorbenen Vater Franz Gastl übernommen... “ MZA, B 14 st., kart. 336, sign. 15/2, fol. 550r.
} 


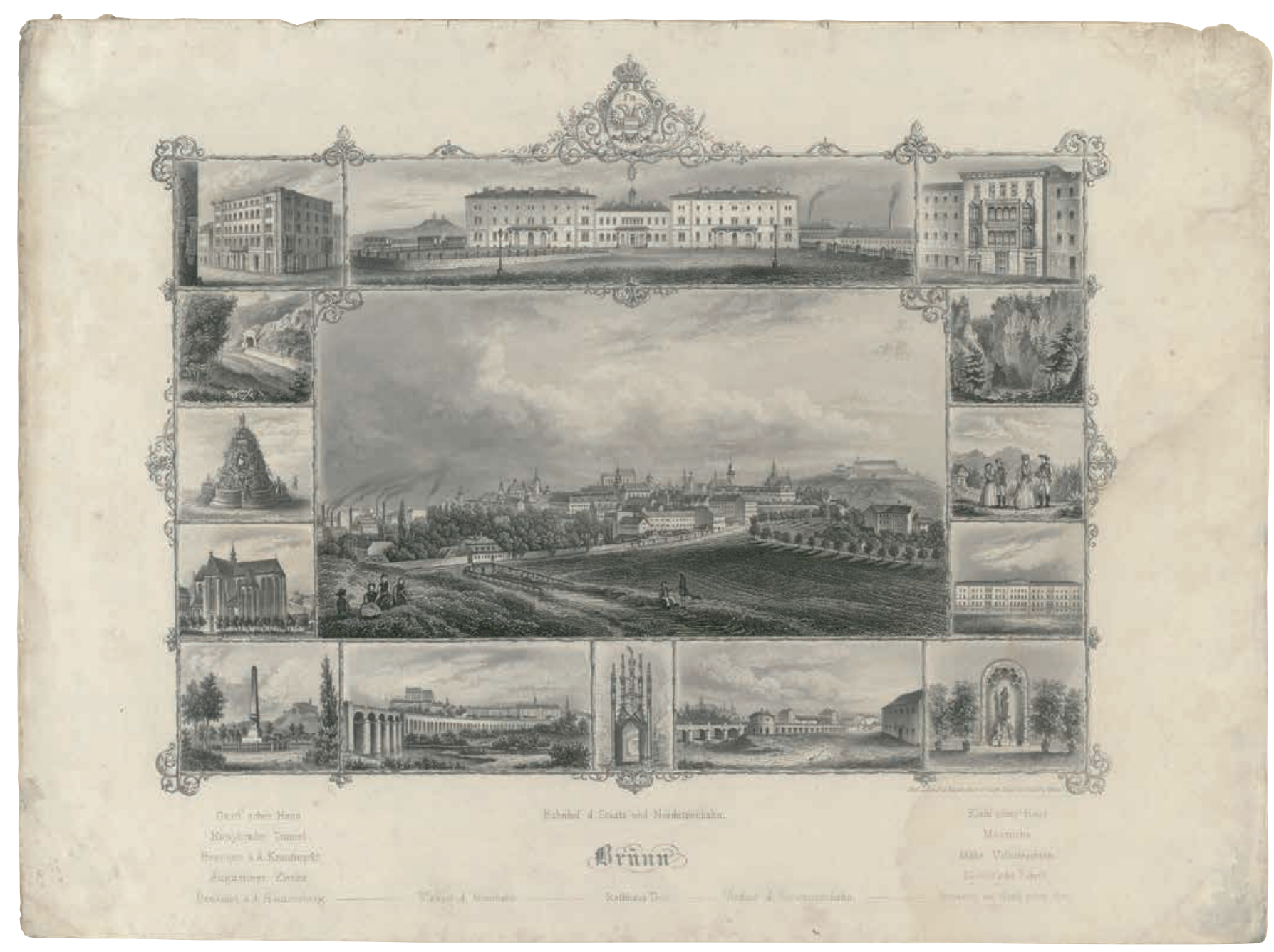

Obr. 4. O významu firmy Franze Gastla svědčí i ocelorytina zachycující brněnské pamětihodnosti. Budova Gastlova knihkupectví se nachází v levém horním rohu. Brünn. Wien u. Triest: Stich u. Druck d. Kunst.-Anst. d. Oestr. Lloyd, [1860]. MZK, sign. Skř.1-0091.416.

půjčovnu knih a periodik. V celém podniku bylo ročně zaměstnáno 70 až 80 osob. ${ }^{48}$

Velikost firmy, kterou Franz Gastl svým potomkům zanechal, dokládá, že se mu podařilo úspěšně navázat na rodinnou tradici. Rozsáhlý moderní podnik, jenž ve své době patřil $\mathrm{k}$ nejvýznamnějším polygrafickým závodům, se nesmazatelně zapsal do dějin knižní kultury a měl vliv nejen na čtenářství a gramotnost moravských obyvatel, ale stal se i jedním z kulturních center Brna.

\section{Prameny:}

MZA (= Moravský zemský archiv v Brně), Fond B 14 Moravské místodržitelství starší (= B 14 st.), kart. 323, sign. 15.

MZA, B 14 st., kart. 324, sign. 15.
MZA, B 14 st., kart. 325, sign. 15/2.

MZA, B 14 st., kart. 333, sign. 15/2.

MZA, B 14 st., kart. 335, sign. 15/2.

MZA, B 14 st., kart. 336, sign. 15/2.

MZA, B 26 Policejní ředitelství Brno, kniha 843.

MZA, Fond E6 Benediktini Rajhrad, kart. 110, inv. č. 1673, sign. D.c. 2 .

\section{Literatura:}

Beschreibung 1841: Beschreibung des zur Herrschaft Rossitz bei Brünn gehörigen Riczker Neuhofes, erbaut im Jahre 1838 und 1839. Brünn: Gedruckt bei Franz Gastl, 1841.

Bücher-Verzeichniß 1831-1833: Bücher-Verzeichniß der öffentlichen Leih-Bibliothek des Franz Gastl; Buchhändler. Erstes-Fünftes Heft. Brünn: Franz Gastl, 1831-1833.

\footnotetext{
${ }^{48}$ „Die Ausdehnung meines Buchdruckerei-Etablissements näher zu beleuchten, dürfte wohl entbehrtich sein, und hier die bloße Bemerkung genuzen, daß ich in demselben 2 Schnellpreßen, 4 gewöhnliche Druckpreßen beschäftige und hinsichtlich der gelieferten Arbeiten stets mit den besten Erzeugnißen der Monarchie concurriren kann. Eben ist die Schriftgießerei im sollen Ganze und gibt mit Einschluß der Buchdruckerei und Lithografie, wie auch der nahezu an 20.000 Bände starken Bibliothek, einem Personale von 70 bis 80 Köpfen das ganze Jahr hindurch beschäftigung. [...] Die vorhandenen Presse, Materialienvorräthe an Blei, Lettern, Gieß-Apparaten, dann Papier, Bücher in der Leihanstalt, repräsentiren gering angenommen einen Werth von Zwanzig Tausend-Gulden CMte“ MZA, B 14 st., kart. 336, sign. 15/2, fol. 550v.
} 
Buchhandlungs-Anzeige. Mährisch. Ständische Brünner Zeitung. Intelligenzblatt für Mähren. Nro. 204, 27. Juli 1822. Buchhandlungs-Empfehlung und Dank. Mährisch. Ständische Brünner Zeitung. Intelligenzblatt für Mähren. Nro. 308, 8. November 1829.

Dank und Empfehlung. Mährisch. Ständische Brünner Zeitung. Intelligenzblatt für Mähren. Nro. 286, 17. Oktober 1829.

DIEBL 1839: DIEBL, Alois. Beschreibung der auf dem Gute Křetin [...] zweierlei Dresch- und zweierlei Flachsund Hanf-Brechel-Maschinen mit genauen Zeichnungen auf vier lithographirte Tafeln. Brünn: Franz Gastl, 1839.

ELVERT 1854: ELVERT, Christian de. Geschichte des Bücher- und Steindruckes, des Buchhandels, der BücherCenzur, und der periodischen Literatur, sowie Nachträge zur Geschichte der historischen Literatur in Mähren und Oesterreichisch Schlesien. Brünn: R. Rohrer's Erben, 1854. GÁAL DE GYULA 1841: GÁAL DE GYULA, Nikolaus. Anleitung zur Herstellung zweckmässiger Abtritte, Cloaken, Kanäle etc. etc. ... Brünn: Franz Gastl, 1841.

HEILANDOVÁ 2017: HEILANDOVÁ, Lucie. Brněnský knihkupec, vydavatel a tiskař Johann Georg Gastl jako pokračovatel Svobodovské tiskařské tradice v 19. století. In: Bibliograf mezi regály. $K$ životnímu jubileu doc. PhDr. Jaromíra Kubíčka, CSc. Brno: Moravská zemská knihovna v Brně, 2017, s. 47-56.

HEILANDOVÁ 2019: HEILANDOVÁ, Lucie. Kresleno na kameni. Počátky brněnské a pražské litografie. Brno, 2019. Disertační práce. Masarykova univerzita. Filozofická fakulta.

HORATIUS 1830: HORATIUS, Quintus Flaccus. Epistola ad Pisones De arte poetica ad plures editiones collata, atque in partes et capita divisa, cum praecipuis lectionis varietatibus... Brunae, F. Gastl, 1830.

JANÁK 1987: JANÁK, Jan. Brněnské tiskárny v letech 1848-1918. Od tiskařských oficin $\mathrm{k}$ polygrafickému průmyslu. In: KUBÍČEK, Jaromír (ed.). Knihtisk v Brně a na Moravě. Sborník z konference Brno - 4. záři 1986. Brno: Muzejní a vlastivědná společnost, 1987, s. 43-66.

KIENREICH 1838: KIENREICH, Johann Andreas. Verzeichniss der Verlags-Bücher von Joh. Andreas
Kienreich, Buch- und Kunsthändler in GRAZ, welche auch bei Fr. Gastl, Buchhändler in Brünn zu finden sind. [Graz: Kienreich], 1838.

KÜRSCHNER 1849: KÜRSCHNER, Alois. Ponaučenj pro prádelnj sskoly sepsáno a wěnowáno wysokému sněmu zemskému od Aloise Kürschnera. Brno: tiskem Frantisska Gastla, 1849.

Mährisch. Ständische Brünner Zeitung. Nro. 101, 12. April 1830.

Mährisch. Ständische Brünner Zeitung. Intelligenzblatt für Mähren. Nro. 248. Freitag den 9. October 1842.

Matutinum 1837: Matutinum Sacrae noctis Nativitatis et Resurectionis Domini, in vigilia nativitatis et sabbato sancto cum Appendice benedictionum nonnullarum pro commoditate sacerdotii et chori... Brünn: Franz Gastl, 1837

Neuigkeiten. Jahrg. V. Nro. 57. Montag den 26. Februar 1855.

Officium 1836: Officium defunctorum cum conductu, adjuncto ordine sepeliendi adultos et parvulos ... Brunae: F. Gastl, 836.

RATZER 1837: RATZER, Johann Karl. Poetische Versuche. Brünn: Gastl'sche Lettern, 1837.

SMUTNÝ 2012: SMUTNÝ, Bohumír. Brněnští podnikatelé a jejich podniky 1764-1948. Brno: Statutární město Brno, 2012.

Verzeichniss 1818: Verzeichniss aller in der königl. Hauptstadt Brünn, innerhalb der Stadtmauern liegenden Häuser und derselben Eigenthümer. Brünn: Gedruckt mit Gastlichen Lettern, 1818.

Frantissek Gastl. Krátký životopis. In: Posel Morawský aneb domácj, měsstanský a rolnický Kalendář pro Morawany, Čechy a Slowáky na rok přestupný po narozenj Pána Krista 1856. Dvacátý ročník. Brno [1855].

\author{
| Lucie Heilandová \\ Národní knihovna ČR \\ oddělení rukopisů a starých tisků \\ Klementinum 190 \\ 11000 Praha 1
}

